\title{
THE ACTION OF ACETYLCHOLINE ON THE ISOLATED HEART OF MYTILUS PERNA *
}

\author{
by
}

PAULO SAWAYA and JULIETA KHOURI **

Department of General and Animal Physiology and Institute of Marine Biology of the University of São Paulo. Caixa

Postal 11.230, São Paulo, Brazil.

\section{CONTENTS}

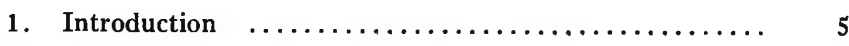

2. Material and methods $\ldots \ldots \ldots \ldots \ldots \ldots \ldots \ldots \ldots, 6$

3. Experiments:

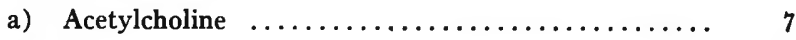

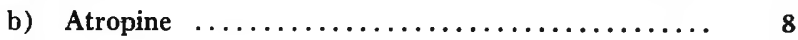

c) Serotonin $\ldots \ldots \ldots \ldots \ldots \ldots \ldots \ldots \ldots \ldots \ldots \ldots, 8$

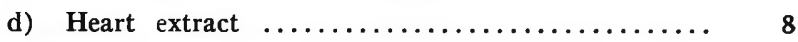

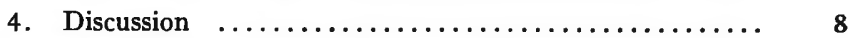

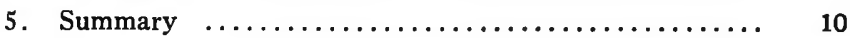

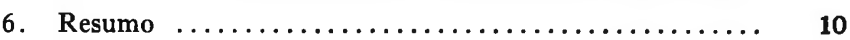

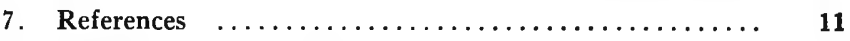

8. Plates $\ldots \ldots \ldots \ldots \ldots \ldots \ldots \ldots \ldots \ldots \ldots \ldots \ldots \ldots \ldots \ldots \ldots \ldots, 13$

1.

\section{INTRODUCTION}

The hearts of some lamellibranchs molluscs are very sensitive to acetylcholine (Prosser and Prosser, 1937) and Smith and Levin (1938, p. 365) have suggested the use of the isolated heart of those molluses as a test for acetylcholine.

* Received for publication on may 5th, 1963.

4* Fellow of the National Research Council. 
Several authors reported that the hearts of Molluscs are myogenic. According to Prosser et al. (1961, p. 397) "ACh inhibits the heart of Molluscs (Gastropoda, Pelecypoda, Cephalopoda) Hearts of some, like Venus, are inhibited by very low concentrations $\left(10^{-12}\right)$, others like Mytilus, are scarcely affected by ACh" Pilgrim (1954, p. 208) indicated that the "isolated strips of Anodonta and Mytilus hearts beat under tension"

Recently the Institute of Marine Biology of the University of São Paulo has started a research programm on the biology of $\mathbf{M y -}$ tilus. During some practical exercises on the cardio-vascular system of those mussels, attention was called to the behaviour on the heart when under the influence of ACh. According to the preliminary results then obtained, we decided to study that point, not only interelation to the behaviour of the Mytilus heart under the $\mathrm{ACh}$ and other drugs such as Atropine and Serotonin, but also to collect the data scattered ond the literature on that controversial point.

2.

\section{MATERIAL AND METHODS}

According to the "Mytilus Programm" of the Institute of Marine Biology, the first parks for breeding Mytilus were built up at the shore of the laboratory at the littoral of São Sebastião. In that park several bunches of Mytilus are growing well, and our material was collected from them; some other Mytilus came from the floats of the harbour of São Sebastião (230 48' 7' S; $45^{\circ} 23^{\prime}$ '29" W) and others from the Urubuqueçaba Island, in the bay of Santos (230 $47^{\prime} 8^{\prime \prime} ; 46^{\circ} 22^{\prime} .25^{\prime \prime} \mathrm{W}$ )

Experiments have been done on a perfusion bath, bubled with air or oxygen, using filtered sea-water as a perfusion fluid. The heart ventricle was cannulated and perfused. The ventricle was connected to a very light heart lever.

Acetylcholine chloride (NBCo), Atropine (Merck), Serotonin Creatinine Sulfate (NBCo), were added to the perfusion fluid in known concentrations. 
Drug solutions in strong concentration were made up in distilled water in values given on $\mathrm{g} / \mathrm{ml}$ of the corresponding salts. Dilutions were made with filtred sea-water brought from the same place of collecting the animals. Such drugs solutions were added to the bathing fluid to produce the desired final concentration.

\section{3.}

\section{EXPERIMENTS}

Only fresh animals were used. Some experiments were done at the laboratory of the Institute of Marine Biology, in São Sebastião, and others in São Paulo. In both places, the experiments were run at room temperature, between $20^{\circ}$ and $25^{\circ} \mathrm{C}$.

\section{a) Acetylcholine (ACh)}

When ACh $\left(1 \times 10^{-10}\right)$ is added to the fluid of a fresh perfused Mytilus heart, increasing of the pulsation occurs and the typical pauses of the normal perfused heart (Fig. 1) abolished. Stronger concentrations of $\mathrm{ACh}\left(1 \times 10^{-8}\right)$ have a positive chronotropic effect. (Fig. 2 and 3 ).

The intensification of the frequency is more evident, when ACh $\left(1 \times 10^{-6}\right)$ is added to the bath, but, in this case, one typical pause of the heart preceeds the increasing of the frenquecy (Fig. 4) That pause is very typical when $1 \times 10^{-4}$ of $\mathrm{ACh}$ is added to the perfusion fluid (Fig. 5) In such a concentration ACh first blocks the heart and, after determine an intensive acceleration of the pulsations. Systolic arrest was observed when more concentrated dosis of ACh ( $1 \times 10^{-2}$ ) was added to the bath (Fig. 6) In this case, recovering of the beatings was observed after one hour or more.

The results mentioned above indicate that the heart of Mytilus is excited by weak concentration of $\mathrm{ACh}$ and blocked by strong ones. In order to prove and to confirm those observation, another series of experiments have been done. Fig. 7 shows that under $.2 \mu \mathrm{g}$ of $\mathrm{ACh}$ the frequency of the hearts beatings is greatly increased. Concentration of the heart beatings is less intense immediately after contact with the drug. There is a lowering of the tone, in- 
dicated by a lowering of the pulsations (Fig. 8) ACh in strong concentration $(10 \mu \mathrm{g})$ provokes a significant systolic arrest of the heart followed after 5-10 seconds by an acceleration of the beats (Fig. 9).

b. Atropine

Atropine has no effect on the heart of Mytilus and does not antagonize the influence of $\mathrm{ACh}$.

\section{c. Serotonin (5-HT)}

Addition to the fluid of fresh, perfused Mytilus heart, of low concentration of Serotonin $(.25 \mu \mathrm{g})$ the heart reacts strongly by an intensive rising of the frequency, but as Fig. 10 indicates those effects are abolished after 20 seconds. The heart recovers its normal pulsations after half a minute.

d. Heart extract

When extract of one heart of 20 to $50 \mathrm{mg}$ in filtered sea-water is added to the perfused fluid the heart reacts by an acceleration of the heart beatings. In this experiment the same heart does not show any effects when perfused with filtered sea-water.

4.

\section{DISCUSSION}

According to Julien \& Vincent (1938) ACh inhibts beat and produces a rise in tone or marked "contracture" of isolated preparations of the ventricle of lamellibranchs. The authors have worked on Mytilus galloprovincialis and they regarded the reaction of the heart as exceptional with respect to the behaviour of mollusc preparations in general. The results with Mytilus perna - indicate that this reaction is not exceptional but a normal one. Pilgrim (1954, p. 209) says that diastolic arrest was found only once in Mytilus when the heart is perfused with $\mathrm{ACh} 10^{-6}$ On the other hand in the case of $\mathrm{M}$. perna the amplitude is affected by weaker concentrations of the drug, but the frequency also is changed. These results do not agree with those of Prosser (1940, p. 10) who found that ACh has primarily a negative inotropic effect on lamellibranchs. Compar- 
ing the results with $M$. perna to those presented by Pilgrim (1. c. p. 211), it seems that the behaviour of Mytilus is more similar to those of Hyridella than with respect to amplitude and frequency increase and systolic arrest. The systolic arrest is very clear in Mytilus perna, as it can be seen in Fig. 6 .

Some of our results confirm those of Pilgrim e. g., the systolic rising in tone, with accompanying transient of lasting increase in amplitude and frequency, and ultimately systolic arrest. Other results, however, do not agree with some of that author, as for instance, the diastolic arrest at high concentrations of $\mathrm{ACh}$.

According to our results there is no doubt that the contractile system of the Mytilus ventricle is influenced by $\mathrm{ACh}$. The concentration of the drug has different effects on the heart muscle, strong concentration blocking the pulsation and weak one provoking acceleration.

Pilgrim's experiments on Mytilus canaliculus (1. c., p. 210, and 211) show that $\mathrm{ACh} 1 \times 10^{-6}$ determine in one case diastolic and in another systolic arrest. Mytilus perna under high concentration of ACh show always both effects, but the diastolic proceeds the systolic arrest, and half a minute after the heart reacts by an increasing of tone and frequency of beats. On the other hand, weak concentrations of $\mathrm{ACh}$ (from $1 \times 10^{-6}$ to $1 \times 10^{-10}$ ) have always the effect of acceleration of the heart beatings.

The fact that the effect of $\mathrm{ACh}$ is not abolished by atropine is probably related to those of blocking and activating the heart beatings, but up to now the reation of the heart has not yet been explained.

The effect of 5-HT and extract of Mytilus'heart are both activating of the tone and frequency of beats. These results may suggest special disposition of the Mytilus heart to react more to potentiate the pulsations than to block them .

This effect is not restricted to the Mytilus heart for similar reaction can be detected with the heart of other Molluscs, e. g., some terrestrial Gastropods, like Strophocheilus oblongus musculus. According to Jaeger (1961, p. 30), the heart of this Gastropod is sensitive to ACh $1 \times 10^{-7}$, showing an inotropic and chronotropic effect. At concentration of $10^{-5}$ and higher, the effect is also inotropic positive, but turns chronotropic negative. 


\section{SUMMARY}

Heart of Mytilus perna is sensitive to acetylcholine in dilutions of $10^{-10}$

Acetylcholine is strong dilutions $\left(10^{-8}\right.$ to $\left.10^{-10}\right)$ increase the pulsations of the heart and in strong concentrations $\left(10^{-4}\right.$ to $\left.10^{-6}\right)$ has a positive chronotropic effect.

Atropine has no effect on the heart of Mytilus perna and does not antagonize the influence of $\mathrm{ACh}$.

Serotonin $(5-\mathrm{HT})$ in low concentration $(.25 \mu \mathrm{g})$ provokes an intensive rising in frenquency of the heart beatings.

When extract of the heart of the same animal in filtered seawater is added to the perfused bath the heart react by an acceleration of the pulsations.

The behavior of the heart of Mytilus perna under different concentrations of $\mathrm{ACh}$ is discussed.

\section{6.}

\section{RESUMO}

Os corações dos Moluscos Lamelibrânquios são sensíveis à Acetilcolina, e o de Mytilus perna apresenta comportamento singular quando submetido a êste éster em diferentes concentrações. Assim, em diluições fortes $\left(10^{-10}\right)$ as características pausas cardíacas desaparecem e as pulsações são regularmente aceleradas. Soluções mais concentradas de $\mathrm{ACh}\left(10^{-4}\right.$ a $\left.10^{-6}\right)$ provocam um efeito cronotrópico positivo.

A atropina não perturba as pulsações cardíacas dêste animal e nem antagoniza a ação da $\mathrm{ACh}$.

A Serotonina (5-HT) na concentração de $.25 \mu \mathrm{g}$ provoca forte reação cardíaca caracterizada pelo intenso aumento da frequiência 
dos batimentos, mas êste efeito é abolido um minuto após o contacto da droga com o músculo cardíaco.

Tendo em vista a ação da $\mathrm{ACh}$ sôbre o coração isolado dêste Lamelibrânquio, fêz-se o extrato dêste órgão em água do mar filtrada, tendo-se verificado que o coração reage com uma aceleração dos batimentos, do mesmo modo como a $\mathrm{ACh}$ em fracas concentrações .

O comportamento do coração sob a influência da ACh em diferentes concentrações é discutido.

It seems that the Molluscs heart have a special sensitiveness to those drugs.

Up to now the knowledge of the histology of lamellibranch heart is still deficient and controversal (Prosser, 1942; Pelgrim, 1954, p. 212) Particularly on the Mytilus perna heart it seems that the inervation comes from the visceral ganglia (Sati personnel communication), but intrinsic innervation of the organ is not yet known.

The effect of $\mathrm{ACh}$ in the heart of Mytilus differ from those obtained by Prosser (1940, p. 101) Prosser \& Prosser (1937, p. 112) on the heart of Venus, and those of Wait (1943, p. 81) on the heart of the same animal.

\section{REFERENCES}

1. PILGRIM, R. L. C., 1954. The Action of Acetylcholine on the hearts of Lamellibranch Molluscs. J. Physiol. 125: 208-214.

2. PROSSER, C. L., 1940. Acetylcholine and nervous inhibition in the heart of Venus mercenaria. Biol. Bull. 78: 92-214.

3. PROSSER, C. L. and BROWN Jr., F. A., 1961. Comparative Animal Physiology. $14+688$. W. B. Saunders Co. ed. Philadelphia.

4. PROSSER, C. L. and PROSSER, H. B., 1937 The action of acetylcholine and of inhibitory nervous upon the heart of Venus. Anat. Rec. 70, Sup. 1: 112 .

5. SMITH, C. C. and GLICK, D., 1939. Some observations on cholinesterase in Invertebrates. Biol. Bull. 75: 365 . 
6. SMITH, C. C. \& LEVIN, L., 1938. The use of the clam heart as a test object for acetylcholine (abstract). Biol. Bull., 75: 365 .

7 WAIT, R. B., 1943. The action of acetylcholine on the isolated heart of Venus mercenaria. Biol. Bull. 85: 79-85.

8. WELSH, J. H. and TAUB, R., 1950. Structure activity relationship of Acetylcholine and quaternary ammonium ions. J. Pharmacol. 99: 334-342. 
8.

P L A T E S 


\section{DESCRIPTION OF THE PLATE 1}

Fig. 1 - Mytilus perna. Normal puslations of the heart.

Fig. 2 - Mytilus perna. Chronotropic effect of ACh $\left(1 \times 10^{-8}\right)$

Fig. 3 - Mytilus perna. Chronotropic effect of ACh (1 $\left.\times 10^{-8}\right)$ The pauses of the normal perfused heart are abolished.

Fig. 4 - The same heart under ACh $\left(1 \times 10^{-6}\right)$; increasing of the frequency after a pause.

Fig. 5 - The same heart. ACh $1 \times 10^{-4}$ The pulsations are blocked followed by a acceleration and increasing of the tonus.

Fig. $6-$ The same heart blocked by ACh $1 \times 10^{-2}$ 

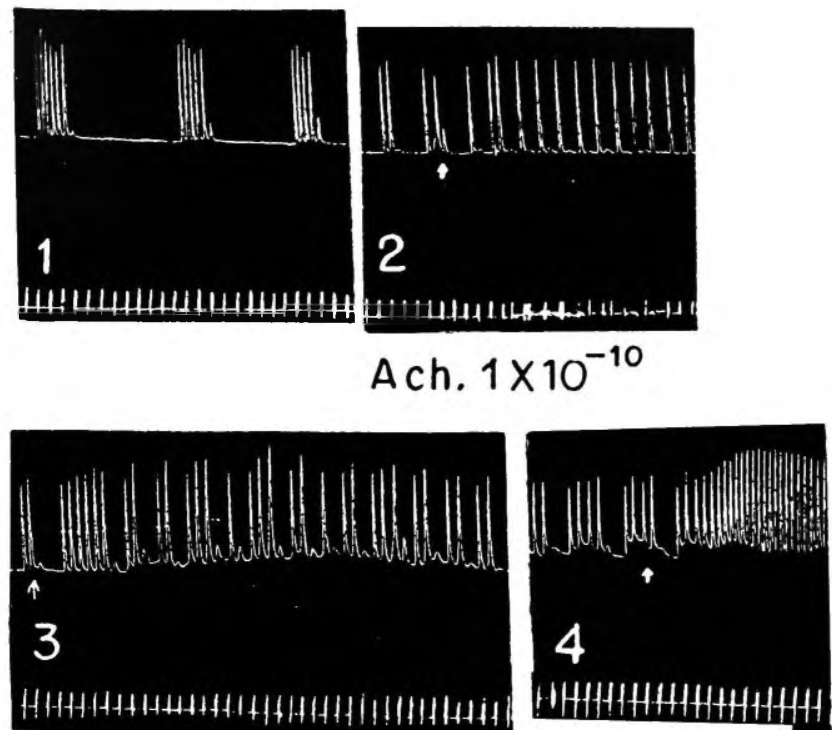

Ach. $1 \times 10^{-8}$
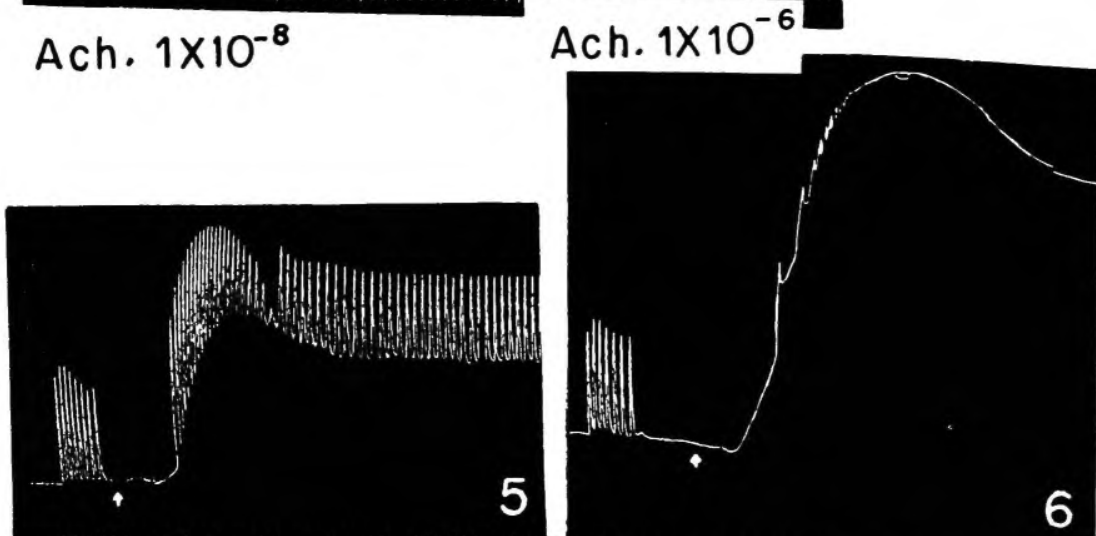

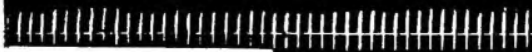

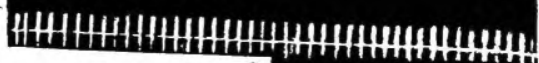
Ach. $1 \times 10^{-4}$ 


\section{DESCRIPTION OF THE PLATE 2}

Reactions of the heart of Mytilus perna to different drugs.

Fig. 7 - Dilluted concentration of $\mathrm{ACh}(.2 \mu \mathrm{g})$ provokes increassing of the frequency and of the tonus.

Fig. 8 - Higher concentration of ACh determines a decreasing of

Fig. 9 - ACh in strong concentration $(10 \mu \mathrm{g})$ blocks the heart following an acceleration of the pulsations.

Fig. 10 - To Serotonin $(.2 \mu \mathrm{g})$ the heart reacts first by an acceleration of the pulsations, followed by a decreasing.

Fig. 11 - To the extract of the Mytilus heart the organ reacts by an acceleration of the pulsations. 

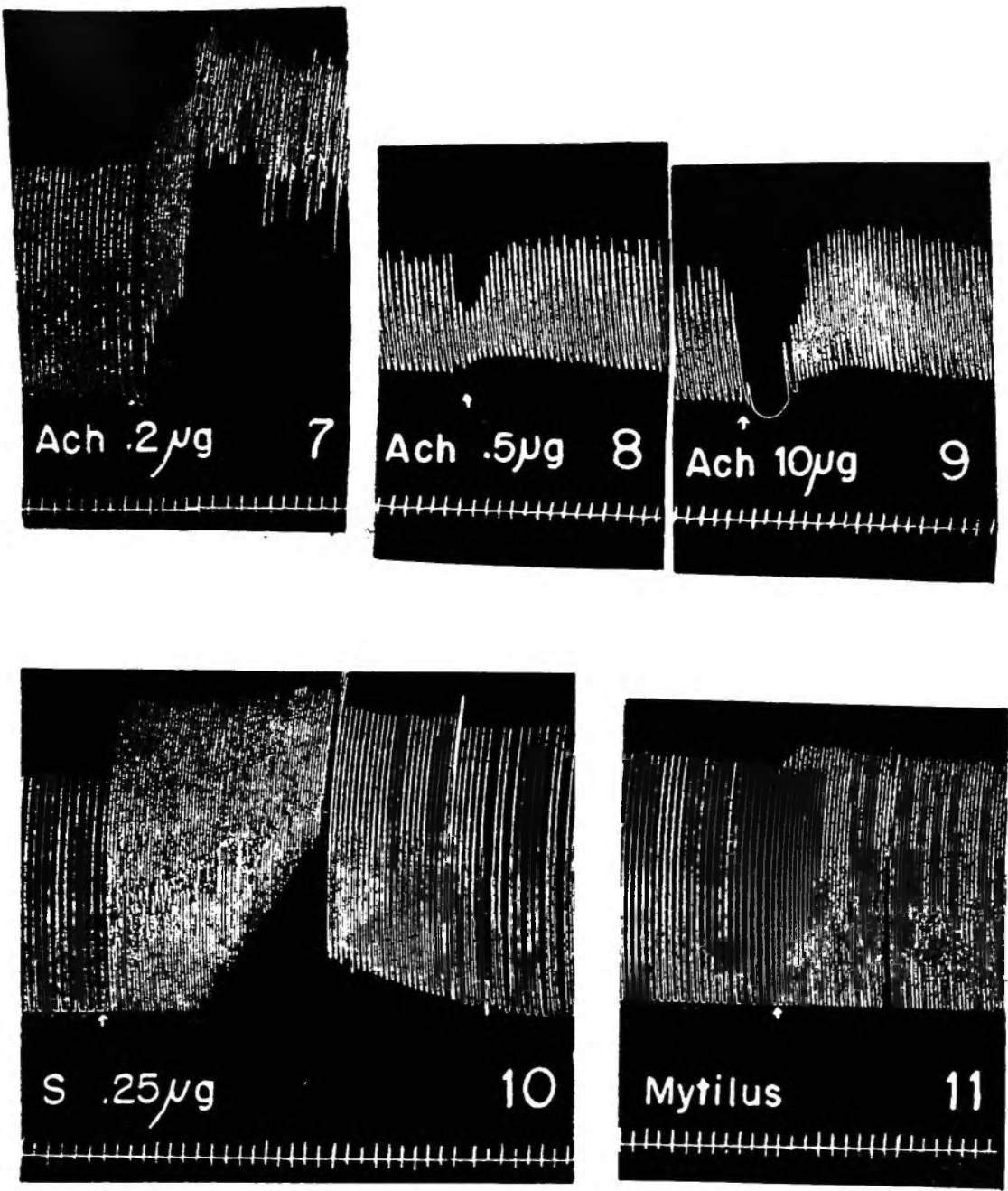
